\title{
Use and cardiovascular safety of transdermal and other granisetron preparations in cancer management
}

This article was published in the following Dove Press journal:

Cancer Management and Research

26 July 2013

Number of times this article has been viewed

Jay W Mason'

Thomas E Moon²

'School of Medicine, University of Utah, Salt Lake City, UT,

${ }^{2}$ Tarizona eHealth Services, Inc, Emeryville, CA, USA
Correspondence: Jay W Mason Mason Cardiac Safety Consulting, I05 Londonderry Court, Reno, NV, 895।I, USA

$\mathrm{Tel}+$ I 7758499910

$\mathrm{Fax}+\mathrm{I} 7758499910$

Email jwm@jaywmason.com

\begin{abstract}
HT}_{3}$ antagonists have been available as oral and intravenous preparations for decades. The availability more recently of transdermal granisetron and the anticipated availability of a subcutaneous granisetron preparation have provided helpful alternatives to patients, and these preparations have been shown to have less potential to prolong QT than other drugs in the class.
\end{abstract}

Keywords: chemotherapy-induced nausea, vomiting, granisetron, QT prolongation

\section{Introduction}

\section{Problem of chemotherapy-induced nausea and vomiting}

Chemotherapy-induced nausea and vomiting (CINV) occurs in $10 \%-90 \%$ of patients, depending on the emetic risk of the chemotherapeutic agent. ${ }^{1,2}$ There is a considerable cost involved, not only for the expense of hospitalization and the direct treatment of CINV, but also because of the loss of workdays and the consequences of delayed chemotherapy administration..$^{3-7}$ There is consistent evidence that $5-\mathrm{HT}_{3}$ antagonist antiemetic therapy has improved this problem without increasing the cost. ${ }^{3-7}$

\section{Unmet needs in CINV treatment}

Delayed nausea and vomiting occurring hours or days after chemotherapy, either as a result of reduced plasma concentrations of prophylactic antiemetics administered at the time of chemotherapy, or inefficacy of ongoing oral antiemetic medications, is a significant management problem. ${ }^{3,8}$ Palonosetron, due to its long half-life, provided a potential solution to this problem, ${ }^{9}$ yet despite its introduction, the problem continues to adversely affect the quality of life of chemotherapy recipients. ${ }^{10}$ An important objective of the granisetron transdermal (TD) delivery system is maintenance of effective plasma concentration of granisetron during and for several days after administration of chemotherapy.

Oral and intravenous (IV) administration of granisetron and other antiemetics is problematic in some patients. Because the oral route is complicated by variable bioavailability and by noncompliance, while the IV route may be too inconvenient, painful or expensive for some patients, other modes of administration have been sought. ${ }^{11}$

\section{Purpose of this report}

The purpose of this report is to review and assess the contribution of TD granisetron to the control of acute and delayed CINV, and to delineate its place in the management 
of CINV. Because of the recent safety concerns related to QT prolongation by $5-\mathrm{HT}_{3}$ antagonists, leading to multiple label changes ${ }^{12}$ and a product recall, ${ }^{13}$ the potential for arrhythmogenesis through TD granisetron is discussed at length.

\section{Methods}

This report is based on a review of the medical literature, available US Food and Drug Administration (FDA) communications and product labels, and a P\&T Product Profiler ${ }^{14}$ provided by ProStrakan (Bridgewater, NJ, USA). In addition, pharmacokinetic and cardiac safety data regarding APF530, a sustained release subcutaneous (SC) preparation of granisetron, was provided by AP Pharma, Inc (Redwood City, CA, USA).

\section{Preparations, pharmacology, and pharmacokinetics of granisetron Currently available preparations of granisetron}

Granisetron is available as an oral tablet ( $1 \mathrm{mg}$ or $2 \mathrm{mg}$ ), and an IV infusion (1 $\mathrm{mg}$ in $1 \mathrm{~mL}$ and $3 \mathrm{mg}$ in $3 \mathrm{~mL}$ ampules), both marketed under the brand name Kytril (Roche, Basel, Switzerland) and as a generic compound. Granisetron in a TD patch (34.3 mg) was approved in 2008 and marketed under the brand name Sancuso (ProStrakan, Inc). A sustained-release SC injection (APF530, AP Pharma, Inc) may become available before or soon after publication of this report, as the US FDA has responded to a new drug application submission for this preparation, and approval during 2013 was established by the sponsor as its objective.

\section{Pharmacology of granisetron}

Granisetron and other selective $5-\mathrm{HT}_{3}$ antagonists block receptors in afferent vagal nerve termini in the gut and in the chemoreceptor trigger zone (CTZ). Vagal receptors in the gut, when stimulated by serotonin release by the intestinal mucosa as a result of chemotherapy, send a signal to the vomiting center and the CTZ that induces nausea and vomiting. Direct stimulation of the CTZ by chemotherapeutic agents may also induce emesis. Granisetron prohibits the emesis reflex by blocking these receptors.

\section{Pharmacokinetics of IV and oral granisetron}

As indicated in the package insert, ${ }^{15}$ the elimination half-life $\left(\mathrm{t}_{1 / 2}\right)$ of IV granisetron (40 $\mu \mathrm{g}$ per $\mathrm{kg}$ ) depends on both age and health status. While the maximum plasma concentration
$\left(\mathrm{C}_{\max }\right)$ is similar among young, elderly, and normal volunteers and patients, terminal elimination is considerably slower in patients with cancer, and nearly as slow in elderly normals compared to young normals (Table 1).

Oral dosing with granisetron $2 \mathrm{mg}$ qd (once a day) in normal volunteers resulted in a mean $\mathrm{C}_{\max }$ of 5.5 nanogram/ milliliter $(\mathrm{ng} / \mathrm{mL})$ and $\mathrm{t}_{1 / 2}$ of 7.9 hours on day $5,{ }^{16}$ while a dose of $1 \mathrm{mg}$ bid (twice a day) in patients with cancer resulted in a $\mathrm{C}_{\max }$ of $5.9 \mathrm{ng} / \mathrm{mL}$, according to the package insert. ${ }^{16}$ $\mathrm{t}_{1 / 2}$ in patients is not reported in the package insert or in the published literature.

\section{Transdermal granisetron Product description}

The granisetron TD patch uses a drug-in-adhesive matrix diffusion method to deliver a predictable dose of granisetron for up to 7 days. The patch is a $52 \mathrm{~cm}^{2}$ rectangle that contains $34.3 \mathrm{mg}$ of granisetron, and delivers it at a rate of $3.1 \mathrm{mg}$ per 24 hours. Transdermal drug delivery is possible because the skin can absorb small, lipophilic molecules by diffusion. The size of the transdermal patch, specific characteristics of the matrix material in which the drug is suspended, properties of the drug itself, and the status of the skin to which the patch is applied determine the rate and extent of drug delivery. While transdermal delivery is generally slow, requiring several hours or days to achieve steady state, the plasma concentrations achieved are predictable and are not subject to rapid change, maximizing the potential for efficacy without toxicities that result from excessive plasma concentration.

\section{Pharmacokinetics of transdermal granisetron}

In a Phase 1 crossover study of twelve normal volunteers, Howell et $\mathrm{al}^{17}$ compared the pharmacokinetics of the $52 \mathrm{~cm}^{2}$ patch to that of oral granisetron $2 \mathrm{mg}$ daily (Figure 1). Several differences are evident. The time at which maximum

Table I Pharmacokinetics of granisetron

\begin{tabular}{|c|c|c|c|}
\hline Health status & Age, years & Mean $C_{\max }$ & Mean $t_{1 / 2}$ \\
\hline \multicolumn{4}{|l|}{ IV granisetron* } \\
\hline \multirow[t]{2}{*}{ Normal volunteers } & $21-42$ & $64.3 \mathrm{ng} / \mathrm{mL}$ & 4.91 hours \\
\hline & $65-81$ & $57.0 \mathrm{ng} / \mathrm{mL}$ & 7.69 hours \\
\hline Patients with cancer & & $63.8 \mathrm{ng} / \mathrm{mL}$ & 8.95 hours \\
\hline \multicolumn{4}{|l|}{ Oral granisetron } \\
\hline Normal volunteers ${ }^{\dagger}$ & & $5.5 \mathrm{ng} / \mathrm{mL}$ & 7.9 hours \\
\hline Patients with cancer ${ }^{\ddagger}$ & & $5.9 \mathrm{ng} / \mathrm{mL}$ & - \\
\hline
\end{tabular}

Notes: $* 40 \mu \mathrm{g} / \mathrm{kg} ;{ }^{\dagger} 2 \mathrm{mg}$ qd; ${ }^{*} \mathrm{mg}$ bid.

Abbreviations: $\mathrm{t}_{1 / 2}$, elimination half-life; IV, intravenous; qd, once a day; bid, twice a day; $\mathrm{ng} / \mathrm{mL}$, nanogram/milliliter; $\mathrm{C}_{\max }$, maximum plasma concentration. 


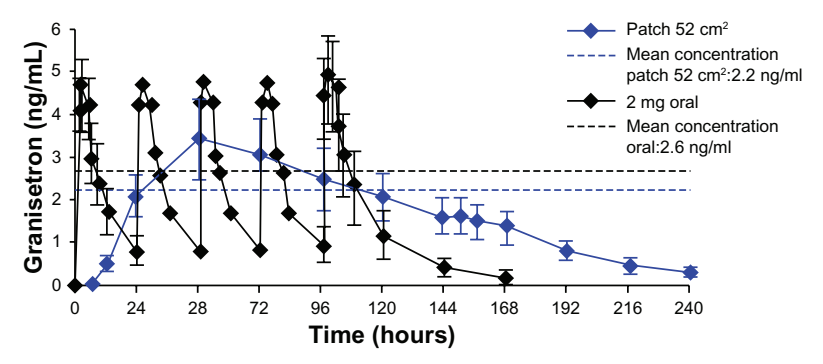

Figure I Plasma concentrations of granisetron resulting from repeated oral dosing ( $2 \mathrm{mg}$ daily) and the Sancuso $52 \mathrm{~cm}^{2}$ TD patch ${ }^{17}$ in normal volunteers. Note: The patch was removed at the end of day 6 (144 hours).

Abbreviations: TD, transdermal; $\mathrm{ng} / \mathrm{mL}$, nanogram/milliliter.

plasma concentration was achieved $\left(\mathrm{T}_{\max }\right)$ was 1.5 hours to 2 hours during oral dosing, and approximately the same $\mathrm{C}_{\text {max }}$ was achieved each day. $\mathrm{T}_{\max }$ for the patch was 48 hours, and $\mathrm{C}_{\max }$ varied substantially from day to day. While $\mathrm{C}_{\max }$ was greater after oral dosing compared to patch administration, mean plasma concentration through 5 days was similar. The $\mathrm{t}_{1 / 2}$ of oral granisetron varied between 6.4 and 7.9 hours, while the apparent $\mathrm{t}_{1 / 2}$ during patch administration was 35.9 hours. Figure 1 shows clearly that the within-day variation in granisetron concentration was much greater during oral administration. It also shows that plasma concentration reached its mean value at 24 hours and its $\mathrm{C}_{\max } 24$ hours later. Thus, the patch must be applied 24 hours to 48 hours before chemotherapy is started.

In a Phase 3 study that included 90 recipients of TD granisetron (Straken Pharmaceutical Ltd, 2007), the plasma concentration curve during patch treatment was very similar to the curve observed in normal volunteers (Figure 2).

\section{Efficacy of transdermal granisetron}

TD granisetron was found to be noninferior to oral granisetron, $2 \mathrm{mg}$, in premarketing clinical trials in patients

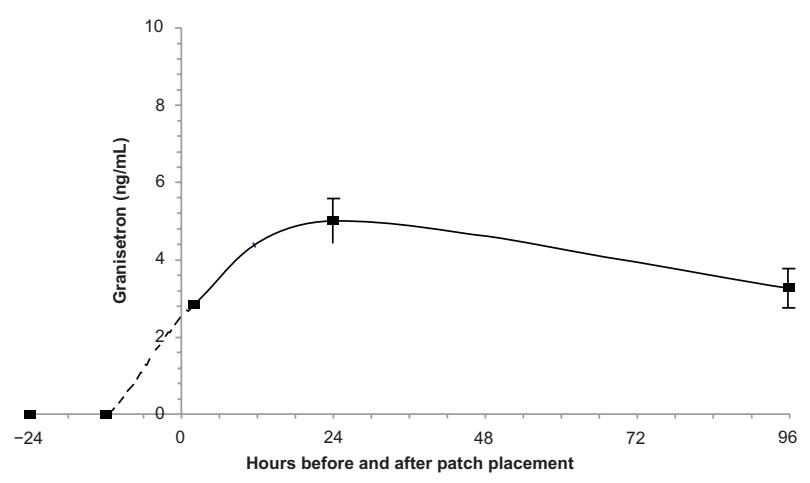

Figure 2 Plasma concentration in patients treated with the TD granisetron patch. Note: Plasma concentration-time curve is very similar to that observed in normal subjects (Figure I).

Abbreviations: TD, transdermal; $\mathrm{ng} / \mathrm{mL}$, nanogram/milliliter. receiving a single dose (Straken Pharmaceutical Ltd, 2007) of chemotherapy and repeated doses ${ }^{19}$ of chemotherapy over 3 to 5 days, in controlling both acute (first 24 hours) and late (24-120 hours) CINV. In the single-day chemotherapy study, ${ }^{18} 210$ patients were randomized in a 1:1 ratio to receive either oral granisetron or the TD patch, both administered once. Total control of CINV (no nausea and no use of rescue medication) was achieved in $52.4 \%$ of patients in the former and $43.7 \%$ in the latter group (not statistically or clinically significantly different).

In the multiple-day study, ${ }^{19}$ in which 323 patients were randomized to receive daily oral granisetron given when chemotherapy was administered, and 318 to receive the TD patch applied once 24 hours before chemotherapy and removed on day 7, complete control of CINV (no more than mild nausea) was reported by $64.8 \%$ in the former group, and $60.2 \%$ in the latter (not significantly different) during the acute phase. Rescue medications were used equally in the two groups during the late phase, when the chemotherapy regimen was of 3 days' duration, and more frequently in the TD patch group when chemotherapy was administered for 4 days or 5 days.

\section{Safety and tolerability of transdermal granisetron}

TD drug delivery, in general, has advantages and disadvantages, as summarized by Patel et al. ${ }^{20}$ Adhesion is a major issue for all transdermally delivered medications. ${ }^{21}$ Loss of adhesion results in reduced drug delivery and can result in inefficacy. Among 308 patients receiving Sancuso in a Phase 3 study (392MD/15/C) ${ }^{22} 64 \%$ had $\geq 90 \%$ adhesion; $90 \%$ had $\geq 75 \%$ adhesion; and two patients ( $1 \%$ ) had complete patch detachment. In another Phase 3 study $(392 \mathrm{MD} / 8 / \mathrm{C}),{ }^{18}$ one of 88 subjects had complete patch detachment. Though considerable work has been done to develop methods to assess completeness of chronic patch adhesion, ${ }^{23}$ there is no organized data in the medical literature against which to compare the adhesion success of Sancuso. The low rate of complete patch detachment in these two Phase 3 studies is impressive, but detachment of at least $10 \%$ of the patch surface in $36 \%$ of patients in the two Phase 3 studies noted is a drawback.

In the same two studies, two of 308 subjects in 392/ $\mathrm{MD} / 15 / \mathrm{C}$ and three of 88 in study $392 \mathrm{MD} / 8 / \mathrm{C}$, or an average of $1.3 \%$, developed skin irritation. ${ }^{18,22}$ Skin tolerance of the Sancuso patch was very good.

The incidence of the most common adverse events reported in the Kytril label for $2 \mathrm{mg}$ oral dosing ${ }^{16}$ and the 
incidence associated with oral granisetron and TD patch granisetron from studies $392 \mathrm{MD} / 15 / \mathrm{C}$ and $392 \mathrm{MD} / 8 / \mathrm{C}$ are summarized in Table 3, which was drawn from Table 6 in the P\&T Profiler. ${ }^{14}$ Patch delivery produces a side effect profile similar to that of oral delivery of granisetron.

\section{Other granisetron preparations and other drug treatment options}

Fourteen specific alternatives to oral and IV granisetron are listed in Table 4. Four are not yet approved for marketing; two are not available in the US; and one is approved only for veterinary use. APF530 is a formulation of granisetron for sustained release after SC injection. It consists of granisetron in a bioerodible poly(ortho ester) polymer that results in slow delivery of granisetron from the injection site into the circulation for as long as a week.

\section{QT prolongation associated with granisetron preparations, other $\mathbf{5}-\mathrm{HT}_{3}$ antagonists}

HERG potassium channel $\left(\mathrm{I}_{\mathrm{Kr}}\right)$ block appears to be a $5-\mathrm{HT}_{3}$ antagonist class effect. Table 2 shows the drug concentration causing 50\% inhibition ( $\mathrm{IC}_{50}$ ) for $\mathrm{I}_{\mathrm{Kr}}$ tail current inhibition by the four members of the class for which data are available. The clinical safety margin for each drug administered at a recommended oral dose was calculated from known physical characteristics of the drugs and published mean $\mathrm{C}_{\text {max }}$ levels.

In December 2010, the US FDA prohibited use of IV dolasetron for CINV because of excessive QTc prolongation. ${ }^{24}$ Its use for control of postoperative nausea and vomiting was not discontinued because of the lower recommended dose, but new warnings were applied to the oral formulation. In 2011, IV dolasetron for any indication was withdrawn from the Canadian market. ${ }^{25}$ The low safety margin during oral dosing, lowest among the four co-classified drugs shown in Table 2, is consistent with these outcomes.
Ondansetron is the most potent $\mathrm{I}_{\mathrm{Kr}}$ blocker on a molar basis among the four $5-\mathrm{HT}_{3}$ antagonists (Table 2), and its safety margin after oral doses of $8 \mathrm{mg}$ is small. The US FDA recently required the drug's manufacturer to perform a thorough QT study of high IV doses used for control of CINV. In June 2012, the US FDA prohibited use of IV ondansetron at doses above $16 \mathrm{mg}$ because of marked QT prolongation noted in the thorough QT study (TQTS) and anecdotal reports of ondansetron-related arrhythmias. ${ }^{26}$ Subsequently, $32 \mathrm{mg}$ ondansetron ampules were withdrawn from the market. ${ }^{13}$ The recommended oral dose of $24 \mathrm{mg}$ administered as three $8 \mathrm{mg}$ tablets over 30 minutes, and IV doses of $16 \mathrm{mg}$ or less are still permitted.

Current labeling of palonosetron no longer includes a warning regarding QT prolongation. Removal of the previous warning in 2008 was based on a TQTS that showed virtually no effect of palonosetron on the QT interval at IV doses as high as $2.25 \mathrm{mg} .{ }^{27}$ Note that palonosetron has the largest safety margin among the four drugs in Table 2 . This results from the fact that it has the highest $\mathrm{IC}_{50}$ concentration and nearly the lowest effective plasma concentration.

Granisetron also has a very high safety margin (Table 2). However, it acquired a new safety warning in October 2009:28

An adequate QT assessment has not been conducted, but QT prolongation has been reported with KYTRIL. Therefore, Kytril should be used with caution in patients with pre-existing arrhythmias or cardiac conduction disorders, as this might lead to clinical consequences.

While a warning of this sort might be appropriate for any drug with a significant interaction with the $\mathrm{I}_{\mathrm{Kr}}$ channel, it is not clear why granisetron is so labeled while palonosetron is not. In fact, IV, TD, and SC preparations of granisetron have been evaluated in thorough QT studies and found to have minimal effect on the QT interval. ProStrakan, Inc, sponsored a TQTS of IV (10 $\mu \mathrm{g}$ per $\mathrm{kg}$ over 30 seconds) and TD (34.3 $\mathrm{mg}$ in a $52 \mathrm{~cm}^{2}$ patch) granisetron, ${ }^{12}$ while AP Pharma, Inc, sponsored a study of IV granisetron $50 \mu \mathrm{g}$ per kg over 3 minutes and its

Table $2 \mathrm{IC}_{50}$ for hERG cardiac $\mathrm{K}^{+}$channel inhibition

\begin{tabular}{|c|c|c|c|c|c|c|c|}
\hline Drug & $I C_{50}(\mu \mathrm{M})$ & $\begin{array}{l}I_{50} \\
\text { reference }\end{array}$ & Mol wt & PB\% & $\begin{array}{l}\text { Oral } \\
\text { dose }\end{array}$ & $C_{\max } *$ & $\begin{array}{l}\text { Safety } \\
\text { margin }\end{array}$ \\
\hline Palonosetron & 6.50 & $\begin{array}{l}\text { European Medicines } \\
\text { Agency }^{22}\end{array}$ & 296.4 & 62 & $0.25 \mathrm{mg}$ & 5.6 & 901 \\
\hline Dolasetron & 5.95 & Kuryshev ${ }^{30}$ & 324.4 & 73 & $100 \mathrm{mg}$ & 229.0 & 31 \\
\hline Granisetron & 3.73 & Kuryshev ${ }^{30}$ & 312.4 & 65 & $2 \mathrm{mg}$ & 5.5 & 605 \\
\hline Ondansetron & 0.81 & Kuryshev $^{30}$ & 293.4 & 73 & $8 \mathrm{mg}$ & 38.1 & 35 \\
\hline
\end{tabular}

Note: *Mean at recommended oral dose, $\mathrm{ng} / \mathrm{mL}$.

Abbreviations: $\mathrm{IC}_{50}$, concentration causing $50 \%$ inhibition of hERG tail current; hERG, human ether-a-go-go-related gene; $\mathrm{K}$, potassium; Mol wt, molecular weight; PB\%, percent protein bound; $\mathrm{C}_{\max }$, maximum plasma concentration. 
Table 3 Incidence of most common adverse events

\begin{tabular}{llll}
\hline $\begin{array}{l}\text { Adverse } \\
\text { event }\end{array}$ & $\begin{array}{l}\mathbf{2} \text { mg oral Kytril } \\
\text { from label } \\
\mathbf{N}=\mathbf{1 4 5 0}\end{array}$ & $\begin{array}{l}\text { Oral } \\
\text { granisetron } \\
\text { development } \\
\text { program } \\
\mathbf{N}=\mathbf{4 0 6}\end{array}$ & $\begin{array}{l}\text { Patch } \\
\text { granisetron } \\
\text { development } \\
\text { program } \\
\mathbf{N}=\mathbf{4 0 4}\end{array}$ \\
\hline Headache & $20 \%$ & $4 \%$ & $3 \%$ \\
Asthenia & $18 \%$ & $<3 \%$ & $<3 \%$ \\
Dyspepsia & $6 \%$ & $<3 \%$ & $<3 \%$ \\
Diarrhea & $9 \%$ & $4 \%$ & $5 \%$ \\
Constipation & $14 \%$ & $5 \%$ & $9 \%$ \\
Abdominal & $4 \%$ & $<3 \%$ & $<3 \%$ \\
pain & & & \\
\hline $\begin{array}{l}\text { Modified with } \\
\text { transdermal delivery system: a formulation for chemotherapy-induced nausea and }\end{array}$ \\
vomiting. P\&T Product Profiler. 20II (36);2:I-30.14
\end{tabular}

sustained-released, SC preparation of granisetron (APF530, $20 \mathrm{mg}$ ) (AP Pharma Inc, 2012).

In the ProStrakan study, 240 subjects were randomized to four parallel treatment arms, including the two granisetron preparations, placebo, and oral moxifloxacin, $400 \mathrm{mg}$. In the primary analysis, none of the placebo-corrected changes from baseline at any time point for either granisetron preparation exceeded 1.9 milliseconds (msec), and the maximum observed $90 \%$ upper confidence boundary was $6.88 \mathrm{msec}$, well below the threshold of $10 \mathrm{msec}$ for regulatory concern. In addition, the linear ddQTcF-plasma concentration model (Figure 3) showed a very shallow positive slope of $0.157 \mathrm{~ms} /$ $(\mathrm{ng} / \mathrm{mL})$ for the relationship, which predicted a ddQTcF of only $4.79 \mathrm{msec}$ for the maximum individual plasma concentration observed in the study $(26.1 \mathrm{ng} / \mathrm{mL})$. The ddQTcF refers to baseline and placebo-correct QTcF.

In the AP Pharma study, a crossover trial involving 51 completers, the largest change in $\mathrm{ddQTcF}$ in the linear mixed-effects model for either granisetron preparation was $3.75 \mathrm{msec}$, and the largest $90 \%$ upper boundary was $6.89 \mathrm{msec}$. Many ddQTcF values were negative. The log-linear pharmacokinetic-pharmacodynamic model (Figure 4) predicted a very shallow negative slope of -0.1326 , and it predicted a ddQTcF value of $1.37 \mathrm{msec}$ for the highest observed plasma concentration $(82.1 \mathrm{ng} / \mathrm{mL})$.

These two thorough QT studies indicate that granisetron has minimal effect, if any at all, on the QT interval at or below the highest plasma concentrations that was observed in either study $(82.1 \mathrm{ng} / \mathrm{mL})$ during treatment with IV granisetron administered at five-fold standard clinical doses of $10 \mu \mathrm{g}$ per $\mathrm{kg}$ over 30 seconds or $50 \mu \mathrm{g}$ per kg over 3 minutes, or with APF530 containing $20 \mathrm{mg}$ of granisetron in a sustained-release polymer (twice the clinical dosage), or with TD-sustained release administration of $34.3 \mathrm{mg}$ (the standard clinical dose).

\section{Place of transdermal granisetron in CINV treatment}

TD granisetron has an important role in the treatment of CINV. It is a unique preparation with a number of advantages and some disadvantages, related to its TD delivery (Table 5). Perhaps its greatest advantage is the ability to deliver an effective dose of granisetron over at least 5 days, without producing supratherapeutic concentrations that could cause adverse effects. This property makes Sancuso effective in preventing not only acute but also delayed CINV without repeated administration. It is the only antiemetic in its class that can be used by patients unable or unwilling to use the oral or parenteral route. Importantly, it has been shown to have a much lower potential for inducing QT prolongation in comparison to two of the drugs in its class (dolasetron and ondansetron).

The most important drawback in the use of TD granisetron for control of CINV is the need to apply the patch 24 hours to

Table 4 Other 5- $\mathrm{HT}_{3}$ antagonist preparations and other drug therapies for CINV in current use or under development

\begin{tabular}{|c|c|c|c|}
\hline Drug & Class & Approval status & Comment \\
\hline Ondansetron & 5- $\mathrm{HT}_{3}$ antagonist & Approved; 32 mg IV dose withdrawn & \\
\hline Dolasetron & $5-\mathrm{HT}_{3}$ antagonist & Approved; IV withdrawn & \\
\hline Palonosetron & $5-\mathrm{HT}_{3}$ antagonist & Approved & \\
\hline Ramosetron & $5-\mathrm{HT}_{3}$ antagonist & Approved & Japan, SE Asia only \\
\hline Tropisetron & 5- $\mathrm{HT}_{3}$ antagonist & Approved & Not available in US \\
\hline Granisetron SC & 5- $\mathrm{HT}_{3}$ antagonist & Tested clinically; not approved & IV preparation; see Gurpide ${ }^{31}$ \\
\hline APF530 & $5-\mathrm{HT}_{3}$ antagonist & Pending approval & Granisetron in polymer \\
\hline Droperidol & Dopamine antagonist & Approved & Black box warning for $\uparrow \mathrm{QT}$ \\
\hline Dexamethasone & Corticosteroid & Approved & Adjunctive \\
\hline Aprepitant & $\mathrm{NK}_{\text {, antagonist }}$ & Approved & \\
\hline Fosaprepitant & $\mathrm{NK}_{\text {, }}$ antagonist & Approved & Prodrug of aprepitant \\
\hline Maropitant & $\mathrm{NK}_{\text {, }}$ antagonist & Veterinary use only & \\
\hline Vestipitant & $\mathrm{NK}_{\text {, }}$ antagonist & In development & \\
\hline Casopitant & $\mathrm{NK}_{\text {, antagonist }}$ & In development & \\
\hline
\end{tabular}

Abbreviations: CINV, chemotherapy-induced nausea and vomiting; IV, intravenous; SC, subcutaneous; NK, neurokinin I; $\uparrow$ QT, QT interval prolongation; SE, Southeast. 


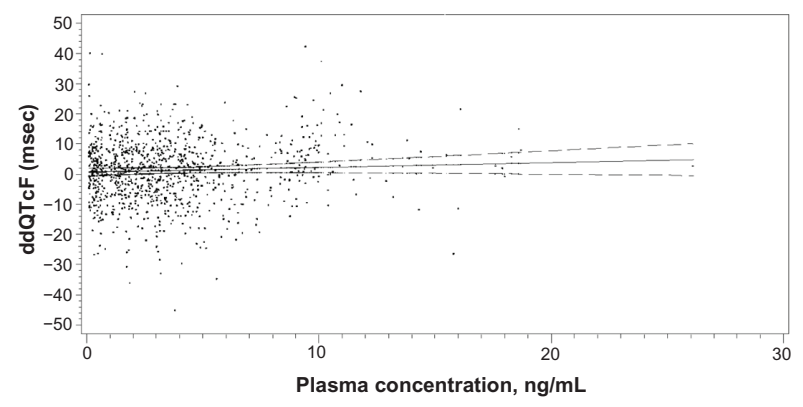

Figure 3 Linear regression of granisetron plasma concentration and associated placebo-corrected change in baseline-subtracted QTcF in the TQTS sponsored by ProStrakan, Inc. ${ }^{2}$

Notes: The slope of the relationship was $0.157 \mathrm{msec} / 9 \mathrm{ng} / \mathrm{mL}$. The model predicted a ddQTcF at the maximum plasma concentration $(26.1 \mathrm{ng} / \mathrm{mL}$ observed in the study of only $4.79 \mathrm{msec}$ ).

Abbreviations: QTcF, QT corrected by the Fridericia formula; TQTS, thorough QT study; ddQTcF, baseline and placebo subtracted QTcF; msec, millisecond; ng/ $\mathrm{mL}$, nanogram/milliliter.

48 hours before chemotherapy is administered. This requirement is a source of unintended noncompliance, but, more importantly, it results in unnecessary exposure and increased expense in patients whose chemotherapy is unexpectedly delayed. Such delays, which may be required for a variety of disease or drug-related comorbidities, are commonplace and are usually initiated immediately before chemotherapy administration - well after the patch would have been applied. For example, Nagel et al $^{29}$ reported at least one delay in chemotherapy administration in 70 of 157 patients $(45 \%)$ treated with a platinum and taxane-based regimen after cytoreductive surgery for ovarian cancer. A potential workaround to avoid unnecessary deployment of the TD patch is to administer

Table 5 Advantages and disadvantages of transdermal delivery of granisetron

Major advantages
Single application improves convenience and compliance
Presence/absence of patch improves compliance
Plasma concentration variability reduction avoids periodic toxicity and
inefficacy
Minor advantages
Added alternative to other treatments
Discomfort of parenteral administration avoided
Major disadvantages
Must be applied 24 hours to 48 hours before chemotherapy
Loss of adhesion
Minor disadvantages
Skin irritation
Not applicable in acute treatment of CINV
Need to protect patch from water and perspiration

Abbreviation: CINV, chemotherapy-induced nausea and vomiting.

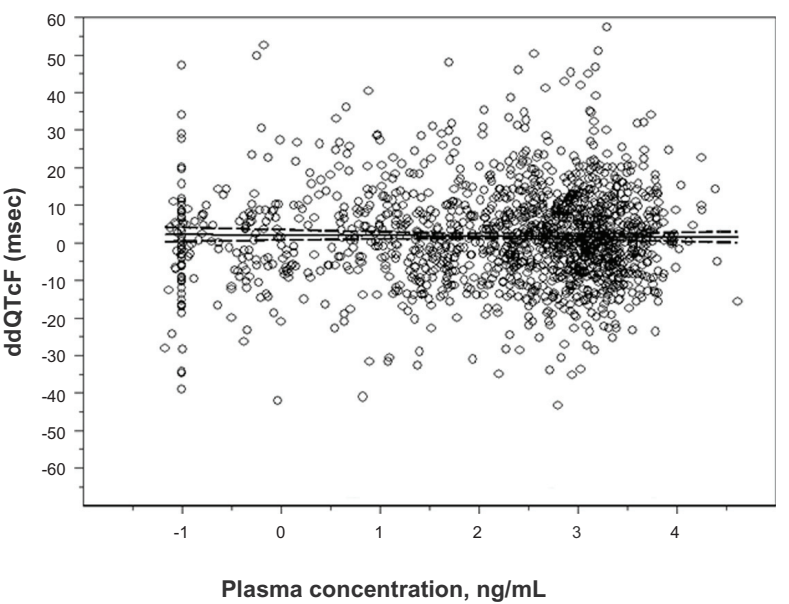

Figure 4 Linear regression the natural log of granisetron plasma concentration and associated placebo-corrected change in baseline-subtracted QTcF in the TQTS sponsored by AP Pharma Inc (20I2).

Notes: The slope of the relationship was $-0.1326 \mathrm{msec} / 9 \mathrm{ng} / \mathrm{mL}$. The model predicted a ddQTcF at the maximum plasma concentration $(82.1 \mathrm{ng} / \mathrm{mL}$ observed in the study of only $1.37 \mathrm{msec}$ ).

Abbreviations: QTcF, QT corrected by the Fridericia formula; ddQTcF, baseline and placebo subtracted QTcF; TQTS, thorough QT study; msec, millisecond; ng/ $\mathrm{mL}$, nanogram/milliliter.

oral or parenteral granisetron on the day of chemotherapy administration and apply the TD patch on the same day.

\section{Conclusion}

TD granisetron is a welcome addition to the available treatments for CINV. Though new preparations of existing drugs and new chemical entities are under development, Sancuso has a firm position in the prophylaxis of nausea and vomiting for the foreseeable future.

\section{Disclosure}

Both authors provided consultative support to AP Pharma, Inc, and to ProStrakan, Inc, that is unrelated to this report and its contents. The authors have no other conflicts of interest to disclose.

\section{References}

1. Gralla RJ, Osoba D, Kris MG, et al. Recommendations for the use of antiemetics: evidence-based, clinical practice guidelines. American Society of Clinical Oncology. J Clin Oncol. 1999;17(9):2971-2994.

2. Roila F, Hesketh PJ, Herrstedt J. Prevention of chemotherapy- and radiotherapy-induced emesis: results of the 2004 Perugia International Antiemetic Consensus Conference. Ann Oncol. 2006;17(1):20-28.

3. Ihbe-Heffinger A, Ehlken B, Bernard R, et al. The impact of delayed chemotherapy-induced nausea and vomiting on patients, health resource utilization, and costs in German cancer centers. Ann Oncol. 2004; 15(3):526-536.

4. Stewart DJ, Dahrouge S, Coyle D, Evans WK. Costs of treating and preventing nausea and vomiting in patients receiving chemotherapy. J Clin Oncol. 1999;17(1):344-351. 
5. Sykes AJ, Kiltie AE, Stewart AL. Ondansetron versus a chlorpromazine and dexamethasone combination for the prevention of nausea and vomiting: a prospective, randomized study to assess efficacy, cost effectiveness, and quality of life following single-fraction radiotherapy. Support Care Cancer. 1997;5(6):500-503.

6. Tina Shih YC, Xu Y, Elting LS. Costs of uncontrolled chemotherapyinduced nausea and vomiting among working-age cancer patients receiving highly or moderately emetogenic chemotherapy. Cancer. 2007;110(3):678-685.

7. Vanscoy GJ, Fortner B, Smith R, Weber R, Rihn TL. Preventing chemotherapy-induced nausea and vomiting: the economic implications of choosing antiemetics. Community Oncology. 2005;2(2):127-132.

8. Hesketh PJ, Sanz-Altamira P, Bushey J, Hesketh AM. Prospective evaluation of the incidence of delayed nausea and vomiting in patients with colorectal cancer receiving oxaliplatin-based chemotherapy. Support Care Cancer. 2012;20(5):1043-1047.

9. Rubenstein EB. Palonosetron: a unique 5-HT 3 receptor antagonist indicated for the prevention of acute and delayed chemotherapy-induced nausea and vomiting. Clin Adv Hematol Oncol. 2004;2(5):284-289.

10. Bloechl-Daum B, Deuson RR, Mavros P, Hansen M, Herrstedt J. Delayed nausea and vomiting continue to reduce patients' quality of life after highly and moderately emetogenic chemotherapy despite antiemetic treatment. J Clin Oncol. 2006;24(27):4472-4478.

11. Kraut L, Fauser AA. Antiemetics for cancer chemotherapy-induced emesis: potential of alternative delivery systems. Drugs. 2001;61(11): 1553-1562.

12. Mason JW, Selness DS, Moon TE, O’Mahony B, Donachie P, Howell J. Pharmacokinetics and repolarization effects of intravenous and transdermal granisetron. Clin Cancer Res. 2012;18(10):2913-2921.

13. Drug safety communication: updated information on $32 \mathrm{mg}$ intravenous ondansetron (Zofran) dose and premixed ondansetron products. Silver Spring, MD: US Food and Drug Administration; 2012 [cited December 30, 2012.] Available from: http:/www.fda.gov/Drugs/ DrugSafety/ucm330049.htm. Accessed February 12, 2013.

14. Grossman J, Caspi A. Sancuso ${ }^{\circledR}$ Granisetron transdermal delivery system: a formulation for chemotherapy-induced nausea and vomiting. P\&T Product Profiler. 2011(36);2:1-30.

15. Intravenous Kytril. [package insert]. Basel, Switzerland: Roche Laboratories Inc; 1998-2005.

16. Oral Kytril [package insert]. Basel, Switzerland: Roche Laboratories Inc; 2009.

17. Howell J, Smeets J, Drenth HJ, Gill D. Pharmacokinetics of a granisetron transdermal system for the treatment of chemotherapy-induced nausea and vomiting. J Oncol Pharm Pract. 2009;15(4):223-231.

18. Howell J, Clark G, Yellowlees A, Gutierrez-Esteinou R. Efficacy, safety, and tolerability of a transdermal granisetron patch for preventionof single-dose chemotherapy-induced nausea and vomiting: phase II trial results. J Oncol Pharm Pract. 2009;15(Suppl 2):20.

19. Howell J, Yellowlees A, Gutierrez-Esteinou R. Efficacy, safety and tolerability of transdermal granisetron patch for prevention of multiday chemotherapy-induced nausea and vomiting: phase III trial results. J Support Oncol. 2008;6:335. (abstract).
20. Patel D, Chaudhary SA, Parmar B, Bhura N. Transdermal drug delivery system: a review. The Pharma Innovation. 2012;1(4):66-75.

21. Wokovich AM, Prodduturi S, Doub WH, Hussain AS, Buhse LF. Transdermal drug delivery system (TDDS) adhesion as a critical safety, efficacy, and quality attribute. Eur J Pharm Biopharm. 2006; 64(1):1-8

22. Boccia RV, Gordan LN, Clark G, Howell JD, Grunberg SM. Efficacy and tolerability of transdermal granisetron for the control of chemotherapyinduced nausea and vomiting associated with moderately and highly emetogenic multiday chemotherapy: a randomized, double-blind, phase III study. Support Care Cancer. 2011;19(10):1609-1617.

23. Gutschke E, Bracht S, Nagel S, Weitschies W. Adhesion testing of transdermal matrix patches with a probe tack test - in vitro and in vivo evaluation. Eur J Pharm Biopharm. 2010;75(3):399-404.

24. Drug safety communication: Abnormal heart rhythms associated with use of Anzemet (dolasetron mesylate). [webpage on the Internet]. Silver Spring, MD: US Food and Drug Administration; 2010 [cited Dec 17]. Available from: http://www.fda.gov/Drugs/DrugSafety/ucm237081. htm\#safety_announcement. Accessed February 12, 2013.

25. IV dolasetron withdrawal letter. Available from: http://www.healthycanadians.gc.ca/recall-alert-rappel-avis/hc-sc/2011/14633a-eng.php. Accessed on February 12, 2013.

26. Drug safety communication: New information regarding QT prolongation with ondansetron (Zofran). [webpage on the Internet]. Silver Spring, MD: US Food and Drug Administration; June 29, 2012. Available from: http://www.fda.gov/Drugs/DrugSafety/ucm310190. htm. Accessed February 12, 2013.

27. DailyMed. Palonsetron prescribing information. US National Library of Medicine; 2008. Available from: http://dailymed.nlm.nih.gov/dailymed/ lookup.cfm?setid=f4216772-6c37-4ff0-a575-f758390656e3. Accessed February 12, 2013.

28. Kytril (granisetron hydrochloride) injection, tablets and oral solution [webpage on the Internet]. Silver Spring, MD: US Food and Drug Administration; 2009 [cited October 21, 2009]. Available from: http:// www.fda.gov/Safety/MedWatch/SafetyInformation/ucm187526.htm. Accessed February 12, 2013.

29. Nagel CI, Backes FJ, Hade EM, et al. Effect of chemotherapy delays and dose reductions on progression free and overall survival in the treatment of epithelial ovarian cancer. Gynecol Oncol. 2012;124(2):221-224.

30. Kuryshev YA, Brown AM, Wang L, Benedict CR, Rampe D. Interactions of the 5-hydroxytryptamine 3 antagonist class of antiemetic drugs with human cardiac ion channels. J Pharmacol Exp Ther. 2000; 295(2):614-620.

31. Gurpide A, Sadaba B, Martin-Algarra S, et al. Randomized crossover pharmacokinetic evaluation of subcutaneous versus intravenous granisetron in cancer patients treated with platinum-based chemotherapy. Oncologist. 2007;12(9):1151-1155.
Cancer Management and Research

\section{Publish your work in this journal}

Cancer Management and Research is an international, peer-reviewed open access journal focusing on cancer research and the optimal use of preventative and integrated treatment interventions to achieve improved outcomes, enhanced survival and quality of life for the cancer patient The journal welcomes original research, clinical \& epidemiological

\section{Dovepress}

studies, reviews \& evaluations, guidelines, expert opinion \& commentary, case reports \& extended reports. The manuscript management system is completely online and includes a very quick and fair peerreview system, which is all easy to use. Visit http://www.dovepress.com/ testimonials.php to read real quotes from published authors. 